Article

\title{
We Drew a Swastika of Grain: Vernacular Religion in the Tibetan Songs of Nubri, Nepal
}

\section{Mason Brown}

Center for Asian Studies, University of Colorado Boulder, Boulder, CO 80309, USA; mason.brown@colorado.edu

Received: 1 October 2020; Accepted: 4 November 2020; Published: 9 November 2020

\begin{abstract}
The academic study of Tibetan Buddhism has long emphasized the textual, philological, and monastic, and sometimes tended to ignore, dismiss, or undervalue the everyday practices and beliefs of ordinary people. In this article, I show that traditional folk songs, especially changlï, are windows into the vernacular religion of ethnically Tibetan Himalayans from the Nubri valley of Gorkha District, Nepal. While changlü literally means "beer song", and they are often sung while celebrating, they usually have deeply religious subject matter, and function to transmit Buddhist values, reinforce social or religious hierarchies, and to emplace the community in relation to the landscape and to greater Tibet and Nepal. They do this mainly through three different tropes: (1) exhortations to practice and to remember such things as impermanence and death; (2) explications of hierarchy; and (3) employment of spatialized language that evokes the mandala. They also sometimes carry opaque references to vernacular rituals, such as "drawing a swastika of grain" after storing the harvest. In the song texts translated here, I will point out elements that reproduce a Buddhist worldview, such as references to deities, sacred landscape, and Buddhist values, and argue that they impart vernacular religious knowledge intergenerationally in an implicit, natural, and sonic way, ensuring that younger generations internalize community values organically.
\end{abstract}

Keywords: Tibet; Buddhism; song; Nubri; Nepal; Himalaya; mandalization; folk religion

\section{Introduction}

In many cases where textual and oral traditions have existed side by side, Western scholarship has gone through a period of privileging the text before eventually expanding its scope to include the oral and ethnographic. ${ }^{1}$ The study of English ballads was purely textual in the late 19th century, but incorporated more and more the study of melody and performance by the mid-20th century (Child 1889; Moore 1916; Bronson 1952; Groom 2006). The study of Christian chant was rejuvenated from the 1950s by a new concern with the role of orality (Levy 1998; Hughes 1987; Hucke 1980). Because the Western study of Tibetan Buddhism was largely founded by textual scholars, it retained an emphasis on the philological longer than many fields and sometimes seemed unconcerned with the Buddhism of the people-the vernacular expressions of the "Great Tradition" of mahāyāna/vajrayāna Buddhism contained in texts and perpetuated in monasteries (Trewin 1993, p. 377). Vernacular religious practices have sometimes even been dismissed as superstition, or as not being true Buddhism, but rather as syncretism incorporating indigenous practices. Of course, in the past few decades, there have been more and more studies, especially from anthropological and historical perspectives, that used different kinds of texts, such as government documents, letters, and even astrological charts, to get at contexts and interpretations, beliefs and values, social histories, and shared visions of identity in Tibetan culture (Trewin 1993, 1995; Childs and Walter 2000; Smith 2001;

1 An earlier version of this article was presented as a conference paper at the First International Conference on Tibetan Performing Arts, Dharamsala, October, 2019, and is partially drawn from my dissertation (Brown 2018). 
Anand 2003; Ramble et al. 2007, 2013; Roche 2011; Gayley 2016a, 2016b; Townsend 2017; Jansen 2017, 2018; Gawne et al. 2020).

The more textual side of Tibetan Buddhist studies has been somewhat slower to adopt this approach (Jansen 2017; Ramble et al. 2013), but what Berthe Jansen (2017, p. 64) calls a "countermovement" is apparently underway. If this is true, then it must include scholars who have studied songs-particularly gur (Tib. mgur), or songs of realization—as Buddhist texts (e.g., Sörensen 1990; Guenther 1993; Sujata 2004; Schaeffer 2005; Dowman 2010; Braitstein 2011; Quintman 2013; Divall 2014; Ewing 2017). Gur are a genre of folk song composed and sung by Buddhist adepts about their own personal religious experience. They are meant to inspire and instruct lay people, in vernacular language, about a Buddhist worldview and soteriology. The privileging of the textual over the oral and musical present historically in much Western Tibetology is mirrored in traditional Tibetan scholarship and pedagogy (Elsner and Rinpoche 2000). ${ }^{2}$ Tibet has a millennium-long scholastic tradition and an extensive canon of Buddhist texts, which are prolifically memorized and treated as sacred. Because gur are attributed to religious masters, they happen to be the only genre of folk song to appear in Tibetan texts. Other genres, while they exist primarily as oral texts, are nevertheless similarly imbued with religious subject matter, and unlike gur from textual sources, are contemporarily relevant, as they are sung and passed on today.

One such genre, changshay or changlü (chang gzhas; chang glu: "beer song", or "toasting song"), are rife with religiously derived values, and are transmitted orally/aurally—as sound-from older to younger generations in social, communal, and celebratory contexts. ${ }^{3}$ As oral texts that are in contemporary circulation, songs reveal not only social history, but the social present. Songs can be a window into beliefs and practices that might go unnoticed or unremarked upon in everyday life. For example, in one song I recorded in Nubri, there is a line about a swastika drawn of grain. I took this to be some esoteric or symbolic imagery. When I asked about it, however, I was told that when a granary is filled, a swastika is drawn into the surface of the grain with a finger, before closing the lid, a practice I would have been unlikely to have been present during the right season to witness. While it may seem trivial, this episode is emblematic of how songs encode a wide variety of vernacular practices and worldviews that reveal indigenous ontologies and ways of relating to the world. This article will examine the texts of this, and several other changlü for what they tell us about the vernacular religious practice and worldview of ordinary people in Tibetan Buddhist culture.

In 2016 and 2018 I recorded a number of changlï in Nubri, a culturally Tibetan enclave in the Himalayan borderlands of Nepal. ${ }^{4}$ Nubri runs parallel to the Tibetan border in Gorkha district, below the $8156 \mathrm{~m}$ Manaslu peak (Tib., dpung rgyan) as a gorge of the Buri Gandaki River, which drains forested alpine slopes that begin below tree line and dense jungle at lower elevations. Nubri's four major and eight-to-ten lesser villages of stacked-stone houses among terraced fields lie between the elevations of $3800 \mathrm{~m}$ at Samdo in upper Nubri, to $1800 \mathrm{~m}$ at Bi village in lower Nubri, or Kutang. Nubri has had some Tibetan settlement since at least the 13th century, when it belonged to the kingdom of Mangyul Gungthang, or lower Ngari. The ruins of a border-taming fort, or dzong, from this period are still visible in the upper reaches of the valley (Childs 2001, 2004). Nubriwas (i.e., people from Nubri) have historically subsisted on farming and trans-Himalayan trade, and adhere largely to the Nyingma tradition of Tibetan Buddhism. Songs are sung and danced communally at religious festivals and weddings, often to the consumption of arak (distilled spirits) and chang (fermented grain "beer"). Today Nubri is experiencing rapid change due to outmigration and the building of a road connecting the Tibet Autonomous Region of China to Kathmandu (Childs 2001, 2004; Childs and Choedup 2019).

2 This is somewhat superficial, since the Tibetan tradition holds that texts may not be effectively studied, practiced, or even understood, without oral transmissions, empowerments, and instructions.

3 The terms changshay and changlü are used interchangeably in Nubri, and I will do so here.

4 This research was funded by a Fulbright-Hays Doctoral Dissertation Research Abroad Fellowship (2016) and a Firebird Fellowship for the Collection of Oral Literature and Environmental Knowledge (2018). 
While changlü literally means "beer song", and they are often sung while celebrating, they usually have deeply religious subject matter, and function to transmit Buddhist values, reinforce social or religious hierarchies, and to emplace the community in relation to the landscape and to greater Tibet and Nepal. They do this mainly through three different tropes: (1) exhortations to practice and to remember such things as impermanence and death; (2) explications of hierarchy, such as iterating whom is to be respected first, second, third, and so forth (e.g., Lamas, then monks, then ministers, then parents); and (3) reiterations of ritual, such as through the employment of spatialized language that evokes the hierarchies of the mandala. This "mandalization process" (Makley 2007, 2010) has been seen to "recenter" Tibetan masculinities and agency (Gayley 2016a, pp. 20-24) and to de-center the hegemonic narratives of the PRC by placing lamas in higher, or central, positions. Through such spatialization, Nubri songs recenter Nubri in relation to Nepal, and exiled Tibet, as a valorized highland culture in a similar mandalization process. A mandala is a Hindu-Buddhist idealized two- or three-dimensional representation of the cosmos in the form of a circle, with Mt Meru, the hub of all Buddhist and Hindu cosmology, or the primary tutelary deity, at the center, and the four continents, or directionally oriented gates and subordinate deities, at the periphery. Scholars of South Asia have long used mandala theory to describe kingdoms, as in S.J. Tambiah's "galactic polities", a term he coined to describe such kingdoms "as conforming to the mandala [sic] scheme in their arrangement at various levels" (1976, p. 69). ${ }^{5}$ Noé Dinnerstein has also used mandala theory to illuminate ways Ladhaki songs "can be seen to present Ladakhi society as a mandala [sic]" (Dinnerstein 2013a, p. 73). Such mandala explicitly order hierarchies, as well as a center-periphery dichotomy.

In the translations that follow, I will point to such spatializing language and the hierarchies it suggests, as well as elements of Buddhist worldview, such as references to deities, sacred landscape, and Buddhist values. While I am talking specifically about songs from Nubri, these ideas would be familiar in many Tibetan cultural areas.

\section{Yangdakpay Chö La Kyab Su Chi (I Go for Refuge to the Authentic Dharma)}

This song was sung and danced for me by Lama Mingmar Dorje of Tsak village. Lama Mingmar is a local ngakpa (Skt. yoggi, a non-monastic lama who functions as village cleric) of the Tsak Gompa, and acts as umdze (dbu mdzad), or chant master there. I Go for Refuge to the Authentic Dharma is a prime example of Buddhist subject matter in changlï. Even when Nubri people are celebrating, their religion is in their thoughts. The most basic vow in Buddhism is "taking refuge" in the three jewels: the Buddha, or the awakened teacher, the Dharma, or the teachings of the Buddha, and the Sangha, or the ordained community of Buddhist monks. "Refuge" means putting oneself completely in the care of Buddhism, and is akin to baptism in Christianity. Taking the refuge vow is how one becomes a Buddhist.

The song starts with "Sön dang la" (gson dang lags), or "Please listen!", a common incipit in this type of song that announces imminent moral instruction. The first verse refers to the six-syllable mantra of Avalokiteshvara, the bodhisattva of compassion, ōm mani padme hüm. This mantra invokes Avalokiteshvara, for whom Manipadme is an epithet. The meaning of mantras are not the point for the Buddhist practitioner, for the mantra's power is believed to be inherent in its sound, but they do have meaning. In this case, the literal meaning is to address Avalokiteshvara, the "[possessor of] jewel and lotus", for these indeed are the objects most frequently held by the bodhisattva in his iconographic representations. $\bar{O} m$ and $h \bar{u} m$ are purely non-lexical expressions, not requiring translation, but commonly used in the formation of mantras. They are interpreted in many ways, according to context, but are generally taken as utterances bridging the gap between mundane and sacred planes of experience (Kapstein 1997, p. 71).

In terms of the levels of meaning of the syllable $\bar{o} m$, on the inner level, it consists of three sounds, represented by the letters a, $u$, and $m$ (Gyatso and Lama 2009), which represent the "three gates

5 See (Aulino et al. 2013) for a detailed discussion of Tambiah's concept of "galactic polities". See also (Chutintaranond 1990) for a discussion of the use of mandala theory in analyzing ancient South-Asian kingdoms, and (Yü 2014). 
of virtue". On the outer level, in both Buddhism and Hinduism, $\bar{o} m$ is believed to be the sound of the universe. On the secret level, it contains the other five syllables within itself. Thus one can chant the mantra of Avalokiteshvara merely by uttering " $\bar{m} m$ ".

The song goes on to exhort the listener to not be lazy "like a cow", but to take heed of impermanence and practice the dharma now, in this life. ${ }^{6}$ This is one of the most common tropes of Tibetan Buddhism. Indeed, this idea is instilled in the preliminary practices (sngon 'gro) of all four major schools of Tibetan Buddhism as "the four thoughts that turn the mind" (blo ldog rnam bzhi) away from samsaric occupations and toward the dharma. Before a student can advance to higher practices, he or she must contemplate these four thoughts: (1) precious human birth, or the fact that we are blessed, through our karma, with the only type of birth that enables us to practice the dharma; (2) impermanence, or the fact that these conditions will not last, and if not taken advantage of, will be wasted; (3) karma, or the fact that our present actions will affect our future; and (4) suffering, or the fact that our samsaric existence will never be satisfactory, and the only way to remedy this is to practice the dharma (Mingyur and Tworkov 2014). These ideas have long permeated Buddhist texts and sermons, and would be immediately familiar to any Tibetan Buddhist. The song implores the listener to visualize Avalokiteshvara, to recite his mantra unceasingly, and most poetically, to "Write the six syllables on fine paper" and "Offer it to the hand of the Lord of Death". Contemplation of impermanence and the certainty of death is not only one of the preliminary practices known as the four thoughts that turn the mind, but is a universal element of texts known as "Stages of the Path" (lam rim) in Tibetan Buddhism, in which such practices are codified.

\section{I go for Refuge to the Authentic Dharma ${ }^{7}$}

Please listen! The secret $\bar{o} m$ has [the five syllables]: ma ni pad me hūm

I go for refuge to the authentic dharma

Please listen! Don't habitually sleep like a cow, get up!

Without sleeping, make offerings to the excellent deity

Please listen! Meditate on Avalokiteshvara with undistracted body recite without distraction, enumerate the six syllables

Please listen! Write the six syllables on fine paper

Offer it to the hand of the Lord of Death

Please listen! There is no point in worldly deeds

While we are here we have to practice dharma

Such texts lay out a process for practicing Buddhism in discrete levels. The first is the contemplation of the rarity of acquiring a precious human birth, and the imperative to use the opportunity meaningfully before its inevitable end. ${ }^{8}$ As Donald Lopez says, "Since it is possible to accumulate the causes of future happiness now, this fear of death serves to motivate religious practice. If one fears death now and is moved by that fear to take action to establish the causes of an auspicious rebirth in the next life,

6 Geoff Childs points out that bovine references may be "a common way of calling someone not just lazy but also too dull to study religion," citing similar language in Milarepa's descriptions of Nubri (communication with the author, 14 March 2018).

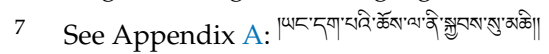

8 A "precious human birth" is one that is endowed with "leisure and opportunity." Leisure means being free from the eight impediments of being born in one of the non-human realms of samsaric existence, e.g., hell, animal, hungry ghost, demigod, or god; or being born as a human but in a border region (an uncivilized area), without working sense faculties, or in a region where Buddhism has not spread. Opportunity means being endowed with the five personal opportunities: being born human, in a country where Buddhism is known, having all one's faculties, being free from the five grave sins ("patricide, matricide, killing an arhat (an enlightened disciple of the Buddha), intentionally wounding a Buddha, and causing dissension in the sangha [the community of monks]"); and having five conditional opportunities: "the appearance of a buddha, his teaching the doctrine, the doctrine remaining to the present, followers of the teaching remaining, and the people of the area providing spiritual and physical support out of love for others" (Lopez 1997, p. 423). 
one can then die without fear" (Lopez 1997, p. 424). The text of this song reinforces those concepts in the context of celebratory singing. It is a prime example of the trope of exhortation to practice in an oral text that resembles the literary genre of lam rim. The basic Buddhist principle that samsara will ultimately never be satisfactory, and the traditional logic of karma and rebirth that it is necessarily rare to be born a human are a shown as core beliefs in communities that have until recently, and even to a large extent today, survived on a hardscrabble subsistence lifestyle. That these texts are transmitted orally/aurally, in contexts of celebration, drinking, and communal dancing, internalizes their seemingly harsh message in joyful resignation.

\section{Dro Ya E (Are You Going?)}

This song, sung by Nangmang Bhuti, of Tsak village, talks about three types of deities, or beings, to whom flower offerings should be made: first, the high goddess Wangmo Gyaltsen (dbang mo rgyal tshan - Lady Victory Banner) who, rather than being a heavenly goddess (lha), is probably an earth goddess (sa gzhi tha mo), which reside in the landscape and are propitiated to ensure good harvests and to ward off natural disasters. Second, the middling "demon" (btsen), Yama Yumtso (ya ma yum tsho) are the twelve Yama goddesses, recast here as local spirits. Finally is the nagga $(g l u)$ below, Tsona Rinchen (mtsho sna rin chen), which I was told by Amchi Dorje of Prok, is a nāga that resides in lake Kel in Kutang (lower Nubri). Interestingly, when I told a singer in Sama village, upper Nubri, that I recorded this and other songs in Tsak, she said "oh, those are our songs- they got them from us!" I will be interested to find out, the next time I return to Sama, if the people in upper Nubri claim a different abode for this nāga, but nevertheless the episode shows that meanings and ideas of ownership of these songs can vary from village to village even within Nubri.

Are You Going??

Are you going?

The best flowers, are you going?

are offered to gods above

Are you going?

Are you going?

That god is Wangmo Gyaltsen, are you going?

Please make her happy

Are you going?

Are you going?

The second-best flowers, are you going?

Are offered to the demons between

Are you going?

Are you going?

That demon is Yama Yumtsho, are you going?

Please make her happy

Are you going?

Are you going?

The third-best flowers, are you going?

Are offered to the naggas below

Are you going?

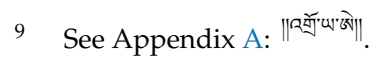


Are you going?

That nāga is Tshona Rinchen, are you going?

Please make him happy

Are you going?

Nāga (skt.) are the serpentine spirits of water, earth, and low places, that protect the environment and must be appeased to prevent diseases and to ensure wealth. While probably referring to these deities' physical location in terms of above, between, and below, the scheme of highest, middling, and lowest according to which the beings mentioned in this song are classified is very common in Buddhist texts in referring to many kinds of beings-for example, human beings are often said to be of high, middling, or low ability and should thus practice the proper level of Buddhist teachings. In this case, the beings referred to are the ones to which flower offerings are made, so the hierarchical relationships outlined are in relation to one another, not to any other kind of being that is not on the list of those to propitiate. The spatialized language here mandalizes these beings in the context of a specific ritual. These types of beings are commonly propitiated in culturally Tibetan areas. The term "flower offering" may have special significance in Nubri. Michael Aris says,

Throughout Tibetan cultural areas, incidental offerings are made in terms of cash or kind, their quantities being prescribed by traditional codes of behavior, but in Kutang [lower Nubri] and Nubri it is simply a flower-surely the purest symbol of offering-that is presented to the lama. It is interesting to note in this regard that the common circumlocution used in literature for offerings made in terms of cash or kind to a high religious personage is in fact the word "flower" (me tog). (Aris 1975, p. 57)

Offerings to propitiate mountain gods, earth-spirits, and nāgas can include flowers, but often consist of food and drink, incense, mantras, and the like. Reading the above passage from Aris makes me wonder if, rather than being a metaphor for all kinds of offerings, the flowers referred to in the song are meant to literally be the only offering to these beings.

This song is an example of the tropes of reiteration of ritual and explication of hierarchy. The landscape is imagined according to elevation, and specific local deities are placed within it along mandalic lines, with explicit instructions on the order in which to make offerings to them, and/or the relative quality of the offerings to be given. Although Buddhism is philosophically non-theistic, it does allow for the existence of non-physical beings like demons, ghosts, and even gods, who are nevertheless subject to impermanence and are trapped in samsara. Tibetan and Himalayan Buddhists at the village level take these beings very seriously as embedded in the landscape, and indeed as being the land's true owners. They are duly propitiated in order to protect harvests, prevent accidents, and promote auspiciousness.

\section{Changshay Nor Min Na (If It's Not a Jewel)}

If it's Not a Jewel was sung by Lama Pema Gyamtso. Like many changlü it has a moral message-that one should appreciate not only the sky, but also the sun, moon, and stars; not only the lama, but the monks and nuns; not only the ministers, but the ordinary people; and not only the parents, but the children. All should be treasured as if they were precious jewels (nor bu). This echoes the revered objects of Buddhist refuge, the Three Jewels (kun chog gsum), or Buddha, Dharma, and Sangha. The last verse refers to "one's kind parents". This is a trope that is especially used in Tibetan Buddhism to teach the development of bodhicitta, or "awakening mind", and compassion by contemplating that in infinite cyclic existence all beings have literally been one's mother numerous times and have been infinitely kind and loving. The hierarchical ordering of persons or objects of veneration, paired with their retinues—root guru/monks and nuns; chief minister/people; parents/sons and daughters (in this case preceded by the sky with its Sun. Moon, and stars, and the Earth with its infinite grains) is a common trope in these songs. It mirrors the ordering of beings depicted in an assembly field, whether physically painted or visualized-gurus, yidams (meditational deities), Buddhas, bodhisattvas, pratyekabuddhas (solitary realizers), śrāvakas/sthaviras (hearers), dākas (celestial beings), and dharmapālas 
(Dharma protectors), with the hierarchy reflected in relative physical size, location in the vertical, and center/periphery placement (Jackson and Jackson 1984, p. 27).

If It's Not A Jewel ${ }^{10}$

Look up to the skies

Don't say there's no jewel

The Sun, Moon, and Stars of the sky

If they are not jewels, what are they?

Look down to the earth

Don't say there's no jewel

All the grains of the earth

If they are not jewels, what are they?

In front of the root guru

Don't say there's no jewel

There are all the monks and nuns

If they are not jewels, what are they?

In front of the chief minister

Don't say there's no jewel

There are all his people

If they are not a jewel, what are they?

In front of one's kind parents

Don't say there's no jewel

There are all their sons and daughters

If they are not jewels, what are they?

The subjects of the verses of this song correspond almost exactly with the subjects of verses in the genre rten 'brel gyi glu, or songs of auspicious connection recorded by Noé Dinnerstein (2013b, pp. 198-219). For example, "rten 'brel lnga pa (The Five Auspicious Signs)", which says, in verse 1, "Now we can be proud of both the sun and moon;" in verse 2, "We can be proud of those lamas that guide us;" in verse 3 , "We can be proud, of that great lord" (high minister); and in verse 4, "We can be proud of our fathers and mothers" (Dinnerstein 2013b, pp. 200-3). While there are historic connections between Ladakh and Ngari, the ancient kingdom of which Nubri was once a part, these are different genres from distant quarters of the Tibetan cultural world, and they have in common core values of the Tibetan worldview. These elements are placed in spatial hierarchies of "up" (the sun and moon in the sky), "down" (the grains of the earth), and in the descending order of their appearance in the text (the lama, high minister, and parents), outlining the mandalic relationships among them. The "grains of the Earth" refers to the precious five grains ("bru lnga). As Khenpo Gyaltsen, a native of Nubri who is now a senior lama in Kathmandu, says, quoting The History of the Ngari Kings, "since the fertility of the land is unspoiled, the five agricultural crops, barley, buckwheat, millet, peas, and beans are all abundant" (Gyaltsen 2014, author's translation).

This song is another example of the trope of mandalizing social and spiritual hierarchies in an idealized Buddhist organization of society within the nesting containers of the Universe and the Earth. Its admonition to regard various positionalities as "jewels", or objects of veneration with high religious value, illuminates a rather conservative view of hierarchy while highlighting a communalism and egalitarianism that characterize communities like Nubri, as well as reiterating an "enlightened" point of view in which everything is perfect as it is.

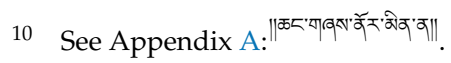




\section{Kathmandu Pilgrimage Praise Song}

This song, sung by Lama Pema Gyamtsho of Tsak village, does not refer specifically to Nubri, but it is all about Kathmandu, and shows Nubri's orientation toward Nepal as a sacred land and expresses the importance of its stūpass. Spatiality and directionality are implied and hierarchies are established: the main st $\bar{u} p \bar{a}$ s are the father and mother; the smaller stūpās are the sons, and Kathmandu is perceived as a mandala, with the sound of the feminine principle as a "golden shawm" placed in the "upper parts".

Kathmandu Pilgrimage Praise Song 11

Considering pilgrimage places at a wedding

I vividly encountered Kathmandu

An amazing spectacle arose

I received great blessings at the stūp $\bar{a}$

Boudha stū $\bar{a}$ is the great father

Swayambu is the great mother

The excess earth and stone between them

Are the happy sons

In the upper parts of Kathmandu city

I heard a golden shawm

It wasn't a golden shawm

It was the speech of the mother and the diākinīs

The supreme pilgrimage places

that are not found in other worlds are there

The verse that says "Boudha is the great father, Swayambu is the great mother, The mud and stone that was left over between them, Are the happy sons" iterates the creation mythology and hierarchy accorded to the sacred sites of the Kathmandu valley not just by Nubriwas, but by Tibetans generally. For them, Boudha is the most important site in the valley. This is not surprising, considering it lies on a historical trade route to India that bypassed Swayambu and Kathmandu, and was an important stopover point for Tibetans plying that route for centuries. Although Tibetans would have visited all the sacred sites in the valley on pilgrimage, and both stūpās were renovated by a lama from Kham, Rigdzin Tsewang Norbu, in the 18th century (Ehrhard 1989), Boudha has long the held higher status. This may be due to the fact that the hereditary abbots of Boudha, the "Chini Lama" (rgya blama) descendants of a Nyingma lama from Szechuan who was given the position by Jung Bahadur Rana in 1859 (Dowman 1993), were important middle-men in a system of tribute payments between Tibet and Nepal (Childs, communication with the author, 13 March 2018). For the Newars, on the other hand, Swayambu is the center of the universe, and Boudha is far less important. ${ }^{12}$ The "happy sons" refers to two smaller stūpās, the Dhando Chaitya at Chabahil, about one mile from Boudha, and Kathe Simbhu at Sigha Bahal in Thahiti, about two miles from Swayambu, which are said by Tibetans to have been made from the leftover materials from the two great stūpass, and to have "self-arisen" after the materials were dumped in those locations. ${ }^{13}$ This differs from the origin stories of these two stūpās among the Newars (the Tibeto-Burman-speaking original inhabitants of the Kathmandu valley). For them, Dhando Chaitya "was built by Ashoka's daughter (Charumati), and Kathe Simbhu was "pulled" to Kathmandu by the tantric powers of Vakvajra" ${ }^{\prime 14}$ For the Newars, Swayambu is the self-arisen stūpa, which is indeed the

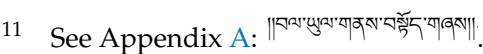

12 Father Gregory Sharkey, communication with the author, 4 August 2017.

13 I have also heard that both the smaller stūpās are "leftovers" from Boudha stūpā.

14 Father Gregory Sharkey, communication with the author, 4 August 2017. 
meaning of its name. The last line of the song, "The supreme pilgrimage places that are not found in other worlds are there" (in Kathmandu), shows the high reverence in which the Kathmandu valley is held by Nubriwas - these supreme pilgrimage sites are not only not found in other countries or lands, but they are not even found in other worlds. This places Nubri in relation to Kathmandu and Nepal. That this is the first song given to me by Lama Pema signals the importance of Kathmandu to these Nepali citizens, and hints at an alliance with Newar Buddhists of the valley which, though longstanding, has certainly increased in recent decades. ${ }^{15}$

This song is another example of the trope of mandalization, which organizes the landscape around sacred mountains and pilgrimage places. It would be interesting to look at the distribution of songs with this complete orientation toward Kathmandu. From the small sample of such songs I have seen, they seem to be common on the southern slope of the Himalaya, where people have long been citizens, or at least subjects of, Nepal.

\section{Milarepa's Song of Realization}

Gur (Tib. mgur) are songs of spiritual experience composed and sung by masters of Tibetan Buddhism. Descended from the Indian/Nepali tradition of doha associated with both tantric Hinduism and vajrayāna Buddhism (Schaeffer 2005), they are typically in vernacular language and tell of the author's spiritual struggles, attainment, and devotion, in a way meant to instruct and inspire lay people. As such, they are a rich repository of indigenous Tibetan ontology. The most famous composer of gur is the 11th-12th century saint, Milarepa, whose One Hundred Thousand Songs (Gur Bum; Tib. mgur 'bum) is a beloved classic (Chang 1977; Stagg and Rinpoche 2017). In Tsak village, I recorded a group of older men singing an example of an oral-tradition Milarepa gur that does not exist in the Gur Bum. Gur are part of a textual tradition dating back a millennium, but it is less well known that they are also a living oral tradition, with songs like this-purported to be ancient-as well as those newly composed, sung at special occasions.

\section{Milarepa's Song of Realization ${ }^{16}$}

Please listen! In the secret $\bar{o} m$ there is mani padme hūm!

I go for refuge to the authentic dharma

In the sky the vulture soars and soars

On the earth the peacock sits and struts

If I, one person, have it, then all have it

If all have it, what joy!

Father Dorje Drakpa stayed in a cliff-cave

My son Rechung, I came from Central Tibet

The cave in the Kathmandu valley is amazing

Not only amazing, but an indivisible field

Cool rice beer is ready to drink

The instructions are not to get drunk

15 The large scale establishment of Tibetan monasticism in Nepal has led to an increase in connections between Nubri and Kathmandu (see Childs 2004; Childs and Choedup 2019), but Newar craftsmen also built statues in Nubri in the early-mid 20th century (Bue 2002).

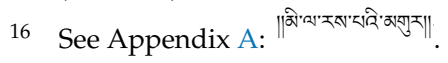


The first lines of this song are essentially the same as I go for Refuge to the Authentic Dharma, above. This could point to a relationship between the two songs, and indeed I go for Refuge also has a gur-like quality. The vulture is a sacred bird in Tibetan culture, and is essential for sky-burials. It also represented Milarepa in a dream seen by his master, Marpa (Lhalungpa 1984, p. 86), and is associated with him-as well as with the male principle - for its solitary austerity and command of the heights. The peacock represents the feminine and is believed to be able to transmute poison, seen as a siddhi, or power, among human yogins. Dorje Drakpa and Rechung, confusingly, both refer to Milarepa's foremost disciple. The final verse refers to the sacrament of alcohol for the tantric practitioner-which is transmuted into nectar with no intoxicating effect.

The fact that this song exists in Nubri shows the affinity Nubriwas have for Milarepa. There is a pilgrimage site near Sama (Rö), in upper Nubri called Naljorphuk (rnal 'byor phug), a cave in which the saint is believed to have meditated. According to Andrew Quintman, The line that says "My son Rechung, I came from Central Tibet $(\ddot{U})^{\prime \prime}$ is curious because Milarepa is thought to have come from Tsang, and that the line that reads "The cave in the Kathmandu Valley is amazing" is even more curious, because although Milarepa is believed to have visited Nepal several times, There is "no record of him using the toponym yam bu rgyal sa" to refer to Kathmandu. ${ }^{17}$ This oral-tradition Milarepa song again shows the orientation of Nubriwas to the Kathmandu Valley as one of their most important pilgrimage sites. As a gur, this song is more personal and less formulaic than the typical changlï, but still makes nods to some of the common tropes. It evokes ritual in the form of mantra, refuge vows, and transforming the substance of alcohol, a component of vajrayāna Buddhist feast rituals. By including a verse about Kathmandu, this song also subtly claims ownership of Milarepa for Nubri.

\section{Kelsang La (How Fortunate!)}

This song talks about celebrating a good harvest and the fact that this good harvest was made possible by performing rituals: planting prayer flags and drawing a swastika in grain. The luck is increased because a new granary has been built, auspiciously providing storage for the bumper crop. There is also a sense of emplacement, in which the landscape is marked in four directions with sacred symbols of good fortune. In Nubri a granary (bang mig) is not a building, but a wooden chest, about half a cubic meter in capacity, which is in the kitchen or living area of the house. When it is filled with the new harvest, a swastika is drawn into the surface of the grain with a finger before sealing the box, as a charm to protect the contents. The swastika is one of the oldest symbols in Buddhism, and represents the Sun, the Buddha, the turning of the Dharma wheel, and the cyclic nature of existence. The drawing of the swastika in the song reflects a vernacular religious ritual that is still followed in households of Nubri to promote auspiciousness, one of the most valued ideas of Tibetan Buddhists.

How Fortunate! $!^{18}$

How fortunate!

This year the harvest was good!

How fortunate!

We made a new granary

What good fortune

What flowers!

We made a new granary

How Happy we are!

How fortunate!

We made a new granary

17 Andrew Quintman, communication with the author, 2019.

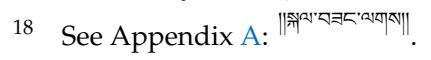


How fortunate!

We drew a swastika of grain

What good fortune!!

What flowers!

We drew a swastika of grain

May our fortune increase!

How fortunate!

On top of the grain swastika

How fortunate!

They say there is a golden prayer flag planted

How lucky we are!

What flowers!

They say a Golden Prayer flag is planted

May the Buddha's teaching increase!

How fortunate!

On top of the golden flag

How fortunate!

They say the flag lines are stretched in four directions

What good fortune!

What flowers!

They say the flag lines are stretched in four directions

May the Buddha's teachings increase

How fortunate!

When the prayer flags are stretched in four directions

How fortunate!

The person who planted the flag became happy in mind

What good fortune!

What flowers!

The person who planted the flag became happy in mind

May happiness increase

As subsistence farmers who supplement their livelihoods by trading (Childs 2001, 2004), the people of Nubri have a great deal invested in the harvest, which can be precarious due to the threat of early frost or hail. This changshay is thus a song of thanksgiving as well as aspiration. Its singing sows the seeds of auspicious connection among the community while expressing humble thanks for a bountiful harvest and, implicitly affirms continued good fortune. This song uses the trope of reiterating specifically vernacular rituals of planting prayer flags and blessing a new harvest with auspicious symbols. In so doing, it inscribes the harvest with the seal of Buddhism, suggesting the greater Buddhist framework through which Tibetan culture has viewed its relationship with the Earth and cycles of life. It is also an example of how, for an outside researcher, small details of vernacular practice can be revealed by songs; and also how, for the community, songs can reinforce and support the intergenerational transmission of those practices.

\section{Conclusions}

I have discussed just six of some thirty-five songs I recorded in Nubri. I chose these songs because they were somehow exemplary, but all of the songs in my sample have some form of Buddhist content. They employ repetitive tropes of exhortation to practice, explication of hierarchy, and mandalization to preserve and pass on religious outlooks and practices. They reveal vernacular rituals, like drawing a swastika of grain, and delineate Buddhist hierarchies and sacred landscape. They admonish the listener and singer alike to practice the Dharma without delay and to celebrate auspicious connection. 
These songs do not tell linear stories, but they often explain hierarchical values, like the relative importance of lamas, parents, ministers, and so forth, or of deities and offerings, as in Dro Ya E. Sometimes they contain specific exhortations to practice, as in Yangdakpa'i Chö la Kyab si Chi. Spatialized references to sacred landscapes, elements of society, and deities are also common. Since folk songs, as oral literature, often carry accumulated cultural knowledge, they are a unique window into the values, beliefs, customs, and worldviews of the peoples to whom they belong. Nubri songs contain a wealth of information about how Tibetan Buddhism has infused the folk culture of the Tibetan periphery in the Himalayas. Furthermore, they transmit such knowledge intergenerationally in an implicit, natural, and sonic way, ensuring that younger generations internalize those values as part of the soundscape. In the current climate of rapid change in highland communities of Nepal, this transmission is being interrupted by the outmigration of youth and its attendant depopulation and demographic aging of those communities. Since I first visited Nubri, I have met many youth who are actively working to preserve their folk song traditions, and so I am not as worried as I first was about these songs disappearing entirely. As Buddhist philosophy tells us, however, impermanence is one of the few things we can count on, and as Nubri's village culture continues to change due to forces of globalization, modernization, and new mobilities, songs like these may become nostalgic relics stripped of their once important functions in village life. At the same time, they may take on new meanings to hold together communities and identities disassociated from their ancestral homelands and striving to maintain connection in a profoundly global, but ultimately floating, world.

Funding: This research was funded by a Fulbright-Hays Doctoral Dissertation Research Abroad grant (DDRA 2016), and a Firebird Fellowship for the Collection of Oral Literature and Environmental Knowledge (2018).

Conflicts of Interest: The author declares no conflict of interest.

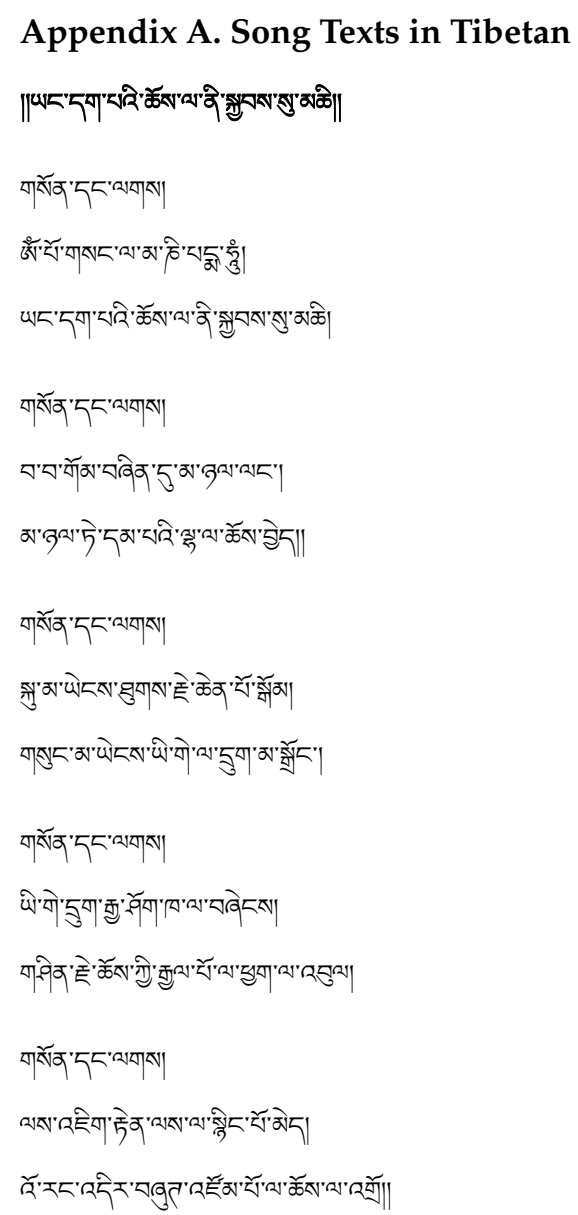




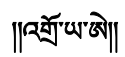

र्ब्चेखण

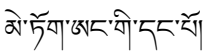

र्ㅟ"खण्डो|

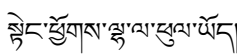

र्ㅟ"w'खे|

R्ㅟ'w'खे|

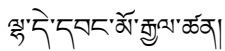

र्ํ"wख्ये|

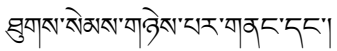

र्ㅟ"wख्से|

र्ㅟ"खण्डो

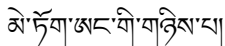

र्ㅟ"wख्ते|

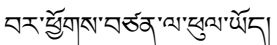

र्ㅟ'एख्ये|

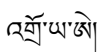

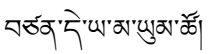

Rर्बे"w'खे।

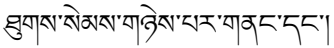

र्ㅟ"खण्डो|

र्ㅟ"w'खे|

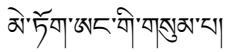

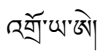

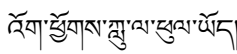

र्ํ"wखोे|

र्ㅟ"wख्से|

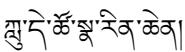

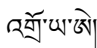

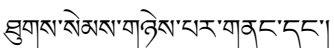

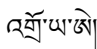




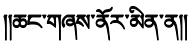

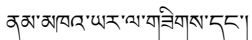

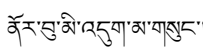

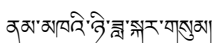

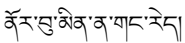

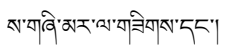

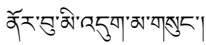

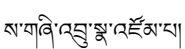

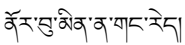

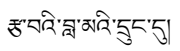

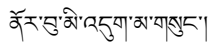

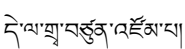

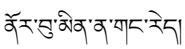

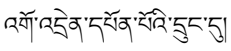

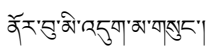

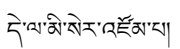

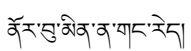

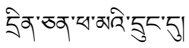

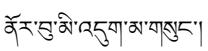

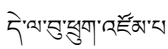

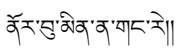

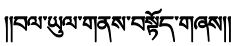

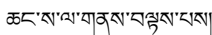

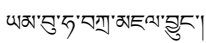

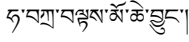

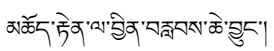

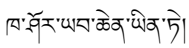

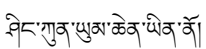

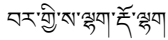

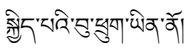

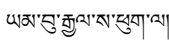

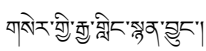

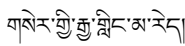

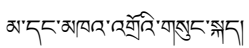

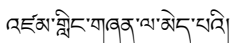

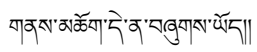




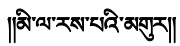

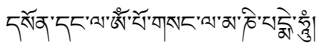

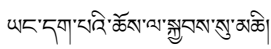

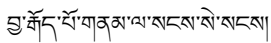

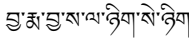

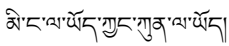

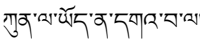

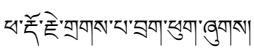

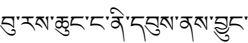

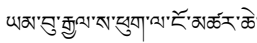

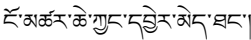

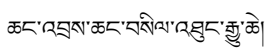

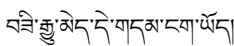

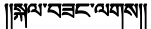

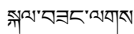

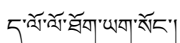

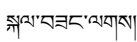

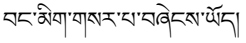

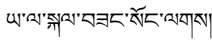

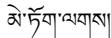

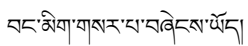

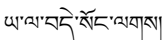

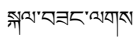

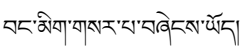 \\ 제

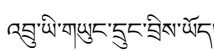

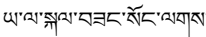 \\ ओे मेखाखयात्रा

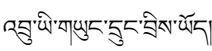

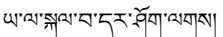

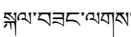

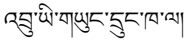

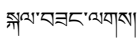

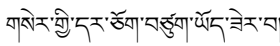

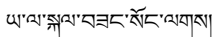

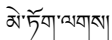

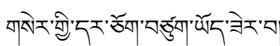




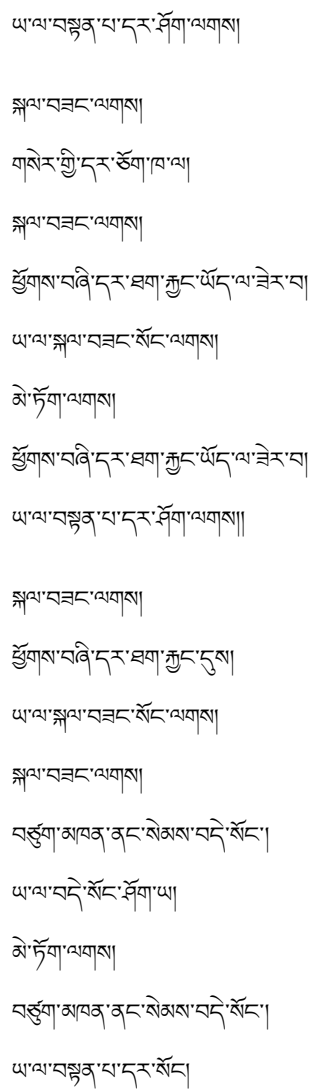

\section{References}

Anand, Dibyesh. 2003. A contemporary story of 'Diaspora': The Tibetan version. Diaspora: A Journal of Transnational Studies 12: 211-29. [CrossRef]

Aris, Michael. 1975. Report on the University of California Expedition to Kutang and Nubri in Northern Nepal in autumn 1973. Journal of the Institute of Nepal and Asian Studies 2: 45-87.

Aulino, Felicity, Miriam Goheen, and Stanley J. Tambiah. 2013. Radical Egalitarianism: Local Realities, Global Relations. Edited by Felicity Aulino, Miriam Goheen and Stanley J. Tambiah. New York: Fordham University Press.

Braitstein, Lara. 2011. The Direct Path: Saraha's Adamantine Songs and the bka' brgyud Great Seal. In Proceedings of the Eleventh Seminar of the International Association for Tibetan Studies. Edited by P. Schwieger. Bonn: IITBS GmbH.

Bronson, Bertrand H. 1952. On the Union of Words and Music in the "Child" Ballads. Western Folklore 11: $233-49$. [CrossRef]

Brown, Mason. 2018. From Pungyen to Palyul: Recentering Identities Through Alliance and Music in Trans-Himalayan Nepal. Ph.D. Thesis, University of Colorado Boulder, Boulder, Colorado.

Bue, Erberto Lo. 2002. Newar Sculptors and Tibetan Patrons in the 20th Century. The Tibet Journal 27: 121-70.

Child, Francis James. 1889. The English and Scottish Popular Ballads. Houghton: Mifflin.

Childs, Geoff. 2001. Claiming the Frontier: A Note on the Incorporation of Nubri within the Borders of Nepal. Studies in Nepali History and Society 5: 217-26.

Childs, Geoff. 2004. Tibetan Diary: From Birth to Death and Beyond in a Himalayan Valley of Nepal. Berkeley: University of California Press.

Childs, Geoff, and Namgyal Choedup. 2019. From a Trickle to a Torrent: Education, Migration, and Social Change in a Himalayan Valley of Nepal. Berkeley: University of California Press.

Childs, Geoff, and Michael Walter. 2000. Tibetan natal horoscopes. The Tibet Journal 25: 51-62.

Christopher Stagg, and Dzogchen Ponlop Rinpoche, transs. 2017, Heruka, Tsangnyön, and Milarepa, eds. The Hundred Thousand Songs of Milarepa: A New Translation. Boston: Shambhala. 
Chutintaranond, Sunait. 1990. Mandala, Segmentary State and Politics of Centralization in Medieval Ayudhya. Journal of the Siam Society 78: 89-100.

Dinnerstein, Noe. 2013a. Songs, Cultural Representation and Hybridity in Ladakh. Himalaya:The Journal of the Association for Nepal and Himalayan Studies 32: 73-84.

Dinnerstein, Noe. 2013b. Ladakhi Traditional Songs: A Cultural, Musical, and Literary Study. Ph.D. Thesis, ProQuest, UMI Dissertations Publishing, Morrisville, NC, USA.

Divall, Jennifer. 2014. Songs of a Wandering Yogi: mgur as a Distinctly Tibetan Genre in the Verse of Godrakpa. Unpublished Ph.D. Thesis, McGill University, Montréal, Canada.

Dowman, Keith. 1993. The Legend of the Great Stupa of Boudhanath; Poulnabrucky: Footprint Publishing. Available online: http://keithdowman.net/books/boudanath-the-great-stupa.html (accessed on 31 March 2018).

Dowman, Keith. 2010. Masters of Mahamudra: Songs and Histories of the Eighty-Four Buddhist Siddhas. Albany: SUNY Press.

Ehrhard, Franz-Karl. 1989. A Renovation of Svayambhunath Stupa in the 18th Century and Its History. Ancient Nepal 114: 1-9.

Elsner, Jas, and Geshe Thupten Jinpa Rinpoche. 2000. Songs of Spiritual Experience: Tibetan Buddhist Poems of Insight and Awakening. Boulder: Shambhala.

Ewing, Benjamin. 2017. The Saraha Of Tibet: How Mgur Shaped the Legacy of Lingchen Repa, Tibetan Siddha. Unpublished Master's Thesis, Kathmandu University, Dhulikhel, Nepal.

Garma C.C. Chang, trans. 1977, Milarepa. The Hundred Thousand Songs of Milarepa: The Life-story and Teaching of the Greatest Poet-saint Ever to Appear in the History of Buddhism. Edited by Heruka Tsangnyön. Boston: Shambhala.

Gawne, Lauren, Gerald Roche, and Ruth Gamble. 2020. The bus doesn't stop for us: Multilingualism, attitudes and identity in songs of a Tibetic community of Nepal. Multilingua 1. [CrossRef]

Gayley, Holly. 2016a. Love Letters from Golok: A Tantric Couple in Modern Tibet. New York: Columbia University Press.

Gayley, Holly. 2016b. T-Pop and the Lama: Buddhist "rites out of place" in Tibetan monastery-produced VCDs. In Religion and Modernity in the Himalaya. Abingdon: Routledge, pp. 63-82.

Groom, Nick. 2006. The purest English': ballads and the English literary dialect. The Eighteenth Century 47: 179-202. [CrossRef]

Guenther, Herbert V. 1993. Ecstatic Spontaneity: Saraha's Three Cycles of Doha. Fremont: Jain Publishing Company, vol. 4.

Gyaltsen, Khenpo. 2014. stod nub ri'i skor mdo tsam brjod pa 'bel gtam skra rtse'i zegs ma zhes bya ba zhugs so (Droplets on Hair-ends: A Brief Expository Discourse on Upper Nubri). Kathmandu: Self-Published.

Gyatso, Tenzin, and HH Dalai Lama. 2009. On the Meaning of Om Mani Padme Hum. Available online: http://enlight.lib.ntu.edu.tw/FULLTEXT/JR-AN/an141056.pdf (accessed on 18 February 2018).

Hucke, Helmut. 1980. Toward a New Historical View of Gregorian Chant. Journal of the American Musicological Society 33: 437-67. [CrossRef]

Hughes, David G. 1987. Evidence for the Traditional View of the Transmission of Gregorian Chant. Journal of the American Musicological Society 40: 377-404. [CrossRef]

Jackson, David, and Janice Jackson. 1984. Tibetan Thangka Painting: Methods and Materials. Boulder: Shambala.

Jansen, Berthe. 2017. 3 Monastic Guidelines (bCa'yig): Tibetan Social History from a Buddhist Studies Perspective. In Social Regulation: Case Studies from Tibetan History. Leiden: Brill, pp. 64-98.

Jansen, Berthe. 2018. The Monastery Rules: Buddhist Monastic Organization in Pre-Modern Tibet. Oakland: University of California Press.

Kapstein, Matthew. 1997. The Royal Way of Supreme Compassion. In Religions of Tibet in Practice. Edited by Donald S. Lopez Jr. Princeton: Princeton University Press, pp. 69-76.

Levy, Kenneth. 1998. Gregorian Chant and the Carolingians. Princeton: Princeton University Press.

Lhalungpa, Lobsang P. 1984. The Life of Milarepa. Boulder \& London: Shambala.

Lopez, Donald. 1997. Mindfulness of death. In Religions of Tibet in Practice. Edited by Donald S. Lopez Jr. Princeton: Princeton University Press, pp. 421-41.

Makley, Charlene. 2007. The Violence of Liberation: Gender and Tibetan Buddhist Revival in Post-Mao China. Berkeley: University of California Press. 
Makley, Charlene. 2010. Minzu, Market and the Mandala: National Exhibitionism and Tibetan Buddhist Revival in Post-Mao China. In Faiths on Display: Religion, Tourism, and the Chinese State. Edited by Tim Oakes and Donald S. Sutton. Lanham: Rowman \& Littlefield Publishers, pp. 127-56.

Mingyur, Yongey, and Helen Tworkov. 2014. Turning Confusion into Clarity: A Guide to the Foundation Practices of Tibetan Buddhism. Berkeley: Shambhala Publications.

Moore, John Robert. 1916. The influence of transmission on the English ballads. The Modern Language Review 11: 385-408. [CrossRef]

Quintman, Andrew. 2013. The Yogin and the Madman: Reading the Biographical Corpus of Tibet's Great Saint Milarepa. New York: Columbia University Press.

Ramble, Charles, Peter Schwieger, and Alice Travers. 2007. The Navel of the Demoness: Tibetan Buddhism and Civil Religion in Highland Nepal. Oxford: Oxford University Press.

Ramble, Charles, Peter Schwieger, and Alice Travers. 2013. Tibetans Who Escaped the Historian's Net. Studies in the Social History of Tibetan Societies. Kathmandu: Vajra Books.

Roche, Gerald, Skal dbang skyid, Sha bo don sgrub rdo rje, Sgrol ma mtsho, Eric Schweickert, Dpa' rtse rgyal and Charles Kevin Stuart. 2011. I, Ya ri a bsod, am a dog: The Life and Music of a Tibetan Mendicant Singer. Asian Highlands Perspectives 10: 177-230.

Schaeffer, Kurtis R. 2005. Dreaming the Great Brahmin: Tibetan Traditions of the Buddhist Poet-saint Saraha. New York: Oxford University Press.

Smith, E. Gene. 2001. Among Tibetan Texts: History and Literature of the Himalayan Plateau. New York: Simon and Schuster.

Sörensen, Per K. 1990. Divinity Secularized-An Inquiry into the Nature and Form of the Songs Ascribed to the Sixth Dalai Lama. Vienna: Arbeitskreis fur Tibetische und Buddhistische Studien, Universitat Wien.

Sujata, Victoria. 2004. Tibetan Songs of Realization: Echoes from a Seventeenth-Century Scholar and Siddha in Amdo. Leiden: Brill.

Townsend, Dominique. 2017. How to constitute a field of merit: Structure and flexibility in a Tibetan Buddhist monastery's curriculum. Religions 8: 174. [CrossRef]

Trewin, Arthur Mark. 1993. Lha-rnga: A Form of Ladakhi Folk Music and its Relationship to the Great Tradition of Tibetan Buddhism. In Anthropology of Tibet and the Himalaya. Zurich: Ethnological Museum of the University of Zurich, pp. 377-85.

Trewin, Arthur Mark. 1995. Rhythms of the gods: The musical symbolics of power and authority in the Tibetan Buddhist Kingdom of Ladakh. Ph.D. Thesis, City University London, London, UK.

Yü, Dan Smyer. 2014. Sentience of the Earth: Eco-Buddhist Mandalizing of Dwelling Place in Amdo, Tibet. Journal for the Study of Religion, Nature and Culture 8: 483-501.

Publisher's Note: MDPI stays neutral with regard to jurisdictional claims in published maps and institutional affiliations.

(C) 2020 by the author. Licensee MDPI, Basel, Switzerland. This article is an open access article distributed under the terms and conditions of the Creative Commons Attribution (CC BY) license (http://creativecommons.org/licenses/by/4.0/). 